\title{
PRECONCENTRATION OF TRACE AND \\ ULTRATRACE AMOUNTS OF PLATINUM AND \\ PALLADIUM FROM REAL SAMPLES
}

\author{
T. Prasada Rao* and Sobhi Daniel \\ Ultratrace Analysis Group \\ Regional Research Laboratory (CSIR) \\ Trivandrum - 695 019. India
}

\section{CONTENTS}

1. Introduction

2. Preconcentration techniques for platinum and palladium
A. Liquid-liquid extraction (LLE)
B. lon exchange
C. Coprecipitation
D. Electrodeposition
E. Fire assay
F. Solid phase extraction (SPE)
G. On-line preconcentration techniques

3. Conclusions

4. Acknowledgement

5. References

\section{INTRODUCTION}

The importance of characterisation of materials for the presence of various analytes at trace/ultratrace concentrations is now well recognised 11.2\%. The trace/ultratrace characterisation has immensely contributed to the development of various branches of science such as metallurgy, enrivonmental science, soil chemistry, geochemistry. agriculture.

*E-mail: tprasadarao(ồrediffmail.com, Fax:_91-471-2491712/2490186 
archaeology, medicine, biotechnology, forensic and surface sciences. The selection of appropriate analytical technique for a given sample analysis involve primary criteria such as selectivity. sensitivity and accuracy and precision /3/ and auxillary criteria like cost of equipment, time of analysis, scope. sampling and standard requirements $/ 3 /$. A comparison of sensitivities obtainable by various analytical techniques for transition elements, toxic heavy metals, lanthanides and noble metals is given in Table 1.

Platinum group metals are used as catalysts for a wide variety of hydrogenation, oxidation, isomerization, cyclization, dehydration and dehalogenation reactions. The corrosion resistance of platinum group metals enables them to be used: i) in electrical, jewellery and glass industries, ii) in extrusion of synthetic fibres and iii) in the manufacture of laboratory utensils. dental and medical devices $/ 4$. Further, alloying platinum and palladium with rhodium. iridium. ruthenium or osmium increases their strength, hardness and corrosion resistance. Selected platinum(II) complex species are effective cytostatics being used in the therapy of some forms of cancer $/ 5 /$.

The determination of noble metals (in particular platinum and palladium) has attracted the interest of analytical chemists as these metals are valuable and their concentration levels are very low in many natural resources. metallurgical intermediates and environmental samples $/ 6 /$. Hence, there is a need for the determination of ultratrace amounts of platinum and palladium at $\mathrm{ng}$ to sub ng levels in view of their reported toxicity. Direct determination of platinum and palladium is still difficult because of the insufficient sensitivity, lack of selectivity, presence of complex matrix, poor precision and accuracy. Preconcentration is widely employed by various researchers $17-9 /$ in conjunction with trace analytical techniques. Preconcentration improves the analytical detection limit and selectivity, increases the sensitivity by several orders of magnitude, enhances the accuracy of the results, and facilitates the calibration. In general, it can be construed as the enrichment process, which involves isolation of the minor component (analyte) from complex matrix or transfer of a particular analyte from one phase to another. Recent developments in the determination of platinum group metals (PGM) have been reviewed earlier $16,10 \%$. Even though solid phase extraction preconcentration of PGM has been reviewed elsewhere, this article was restricted to the applications related to environmental and biotic materials only $/ 11 /$. The present review deals with various preconcentration procedures developed for platinum and palladium since 1990 and discusses them 


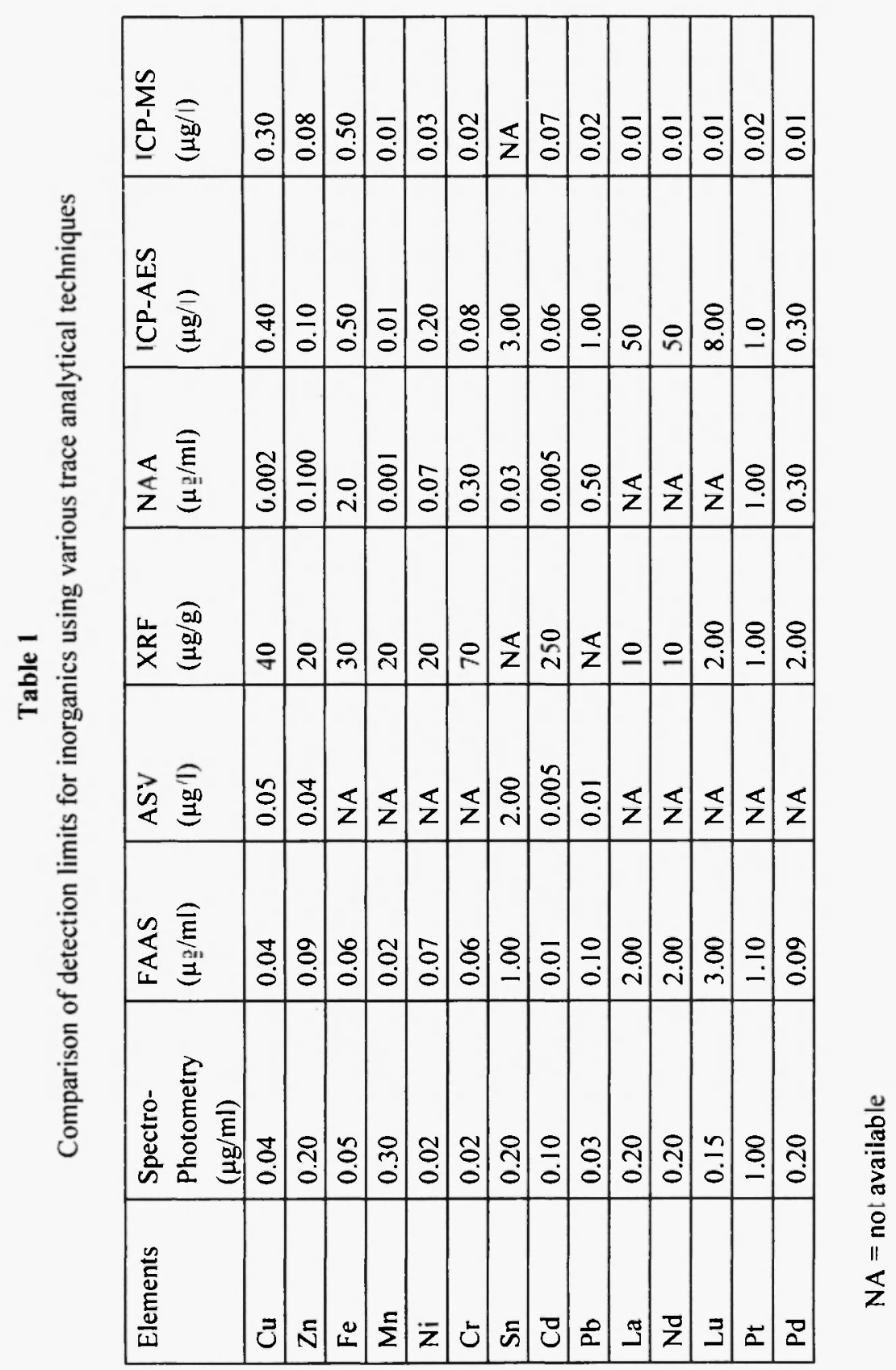


critically in terms of sensitivity, selectivity, precision, adsorption capacity, enrichment factors and applicability to real samples.

\section{PRECONCENTRATION TECHNIQUES FOR PLATINUM AND PALLADIUM}

\section{A) Liquid-Liquid extraction (LLE)}

\section{i) Palladium}

Trace amounts of palladium were preconcentrated by LLE from $\mathrm{HCl}$ medium with quaternary ammonium salts in toluene and stripped by alkaline $\mathrm{NH}_{4} \mathrm{NO}_{3}$ which forms the base electrolyte for subsequent differential pulse polarographic (DPP) determination $/ 12 /$.

A new method was produced for preconcentrative separation of palladium based on the LLE of ion-association complex of $\operatorname{Pd}(\mathrm{SCN})_{4}{ }^{2-}$ ion and cationic potassium complex of dicyclohexyl-18-crown-6/13/. In conjunction with flame atomic absorption spectrometry (FAAS), the preconcentration procedure enabled the determination of traces of palladium in chloroplatinic acid and rhodium chloride.

\section{ii) Platinum}

Microamounts of platinum were preconcentratively separated from common metals by extraction chromatography with GD X501 resin dipped in tributylphosphate $/ 14 \%$. The preconcentrated platinum was eluted with 0.5 $\mathrm{mol} / / \mathrm{HNO}_{3}-0.5 \mathrm{~mol} / 1 \mathrm{NaClO}_{3}$. The recoveries are $89.5-113.9 \%$. which are rather poor. High molecular weight amines such as trioctylamine or diantipyryl methane in 1,2-dichloroethane /15/ were used to preconcentrate platinum after conversion into $\mathrm{SnCl}_{3}^{-}$ligands from hydrochloric acid solutions. The precision of the procedure is quite good as the relative standard deviation (RSD) for synthetic mixtures was below $2.7 \%$.

A better modified calix [4] arene 25,26,27,28-(2-(2-pyridylthio- $N$ oxide)ethoxy) calix [4] arene was synthesized from 25,26,27,28-(2-bromoethoxy) calix [4] arene by reaction with 2-pyridylthiol- $\mathrm{N}$-oxide in the presence of pyridine as base and used as selective extractant for preconcentration of traces of platinum from aqueous solutions into chloroform /16/.

Preconcentrative separation of traces of platinum(IV) and palladium(II) has been investigated as a function of iodide concentration with mesityloxide 
as an extractant $/ 17 \%$. The separation consists of one step of extraction with mesityl oxide from an aqueous phase at $\mathrm{pH} 4$ and $\mathrm{KI}$ concentration in the range $10^{-7}-10^{-6} \mathrm{~mol}^{-1}$. Three step scrubbing with an aqueous phase maintained at $\mathrm{pH} 4$ and $10^{-6} \mathrm{~mol}^{-1}$ in $\mathrm{Kl}$ and one step stripping with $10 \mathrm{ml}$ of water after addition of $40 \mathrm{ml}$ of toluene to mesityl oxide phase. The above procedure is highly selective as seen from the recovery of platinum(IV) and palladium(II) from complex mixtures consisting of other noble and base metals.

\section{B) Ion exchange}

\section{i) Palladium}

A neutral polymeric resin, Amberlite XAD-7. packed in small column was used for preconcentrative separation of palladium from manganese and nickel compounds $/ 18 \%$. After elution, palladium is determined by FAAS. The RSD for 10 successive determinations were found to be lower than $5 \%$ and the detection limit corresponding to 3 times the standard deviation of the blank was found to be $0.07 \mu \mathrm{g} / \mathrm{g}$. A column containing Amberlite XAD-16 has been used for preconcentration of trace amounts of palladium(II) with an adsorption capacity of $35.6 \mathrm{mg} / \mathrm{g}$ which is quite good /19/. The developed preconcentration procedures in conjunction with AAS provide good recoveries $(>98.0 \%$ ) during the determination of as low as $0.051 \mu \mathrm{g} / \mathrm{ml}$ of palladium(II) in alloys. The exchange of palladium(II) ion from chloride and nitrite media onto Duolite GT-73 resin was investigated and the adsorption capacities were calculated to be 0.262 and $0.35 \mathrm{mmol} / \mathrm{g}$ of resin which are fairly good $/ 20 /$.

Dithizone immobilized anion exchange resin was used for preconcentration of trace amounts of palladium and the resulting resin-water suspension was used for quantification using graphite furnace AAS (GFAAS) $121 \%$ The coefficient of variation was $3.94 \%(n=5)$ and detection limit corresponding to the signal to noise ratio of 2 was $5 \mathrm{pg} / \mathrm{ml}$. The developed method has been successfully used for the determination of palladium(II) in water samples.

A novel spherical epoxy-dicyandiamide chelate resin was synthesized simply and rapidly from epoxy resin and used for preconcentration and separation of trace amounts of palladium(11) /22/.400-1000 times excess of $\mathrm{Fe}, \mathrm{Al}, \mathrm{Ni}(\mathrm{II}), \mathrm{Mn}(\mathrm{II}), \mathrm{Cr}(\mathrm{III}), \mathrm{Cu}(\mathrm{I}), \mathrm{Cd}(\mathrm{II})$ and $\mathrm{Pb}$ do not interfere in the determination of palladium(II) by inductively coupled plasma atomic 
emission spectroscopy (ICP-AES). The recoveries were unaffected even after reusing for 7 times. The $\mathrm{RSD}$ of the proposed method is $\sim 1.1 \%$ which is quite good. A new macroporous poly(vinyl amino acetone) chelating resin was synthesized and has been successfully employed for preconcentration of trace amounts of palladium(IV) $/ 23$. The recovery of palladium(IV) added to nonferrous matrices was above $95 \%$ with a good RSD of $\sim 2.0 \%$.

\section{ii) Platinum}

Anion exchange resins have been used for preconcentration of $\mathrm{ng}$ amounts of platinum present in two Chinese ultra basic SRM's $/ 24 /$ and environmental dust $/ 25 /$ samples. The detection limit for the latter procedure in conjunction with isotope dilution ICP mass spectrometry (ICP-MS) was $1.4 \mathrm{ng} / \mathrm{g}$ of dust sample, which is quite impressive. An ion exchange extraction chromatographic procedure was developed for preconcentrative separation of platinum(IV) using $\mathrm{N}$-(hydroxymethyl) thioamide resin as stationary phase $/ 26 /$.

\section{iii) Platinum and palladium}

Platinum group elements were preconcentrated using strongly acidic cation exchange resin, Amberlite CG 120, and have been used for their separation from large amounts of transition elements $127 \%$. The relative standard deviation was $\sim \mathbf{8 \%}$ which is not that impressive. The developed method in conunction with ICP-MS can be used for reliable determination of platinum group metals in sulphide and magnetite minerals from Sudbury, Canada and copper-nickel sulphide ores. A microcolumn packed with cellex$T$ resin was used for preconcentration of platinum and palladium from weakly acidic ( $\mathrm{pH} 4)$ solutions $/ 28 /$. The preconcentrated metals were eluted with $0.01 \mathrm{~mol} / \mathrm{l}$ glycine solution at $\mathrm{pH} 12.0$ for platinum and $4.0 \mathrm{~mol} / \mathrm{l}$ of potassium thiocyanate $(\mathrm{pH}=1)$ or $1.2 \mathrm{~mol} / 1$ of thiourea $(\mathrm{pH}=0.5)$ for palladium and determined by Flame AAS or graphite furnace AAS. Anion exchange resins were used to preconcentrate platinum and palladium and determined by FAAS 29 / or neutron activation analysis (NAA) and ICP-MS 130/. The suitability of the latter procedure for analysing real geological samples like rocks was clearly demonstrated in this paper. Platinum and palladium contents in chromite were established by anion exchange chromatographic preconcentration coupled to ICP-AES determination $/ 31$ /. The recoveries were found to be $96.1 \pm 1.8$ and $96.6 \pm 1.3 \%$ respectively. 
Traces of platinum and palladium were preconcentrated with psulfophenylaxochromotropic acid chelate forming resin from weakly acidic solutions and determined by FAAS /32/. The recoveries are not satisfactory as they vary from $94-105 \%$. Chelex-100 was used for preconcentration of platinum and palladium present in geological and industrial materials and determined by radiochemical version of NAA /33/. The method was verified by determining platinum and palladium in SARM-7 and PTC-I reference materials certified for noble metal content, and shows good agreement. Metal fix-chelamine resin was employed for preconcentration of precious metals in geological and related materials and determined with ICP-MS $134 \%$. The detection limits are 2.0 and $1.5 \mathrm{ng} / \mathrm{g}$ for platinum and palladium respectively. Macroporous resins containing imidazoline groups were tested for preconcentration of platinum and palladium $/ 35,36$ / and determined by ICPAES. The adsorption capacities for platinum and palladium were calculated to be 1.57 and $2.26 \mathrm{mmol} / \mathrm{g}$, which are higher compared to other chelating resins described earlier. The former procedure was applied to analysis of metal smelter samples. Alizarin Red $S$ chelate resin column $/ 37 /$ was employed for preconcentration of platinum and palladium from $0.1 \mathrm{~N} \mathrm{HCl}$ solutions and eluted with $3 \%$ acidic thiourea. This procedure in conjunction with FAAS was successfully used for analysis of geological samples. The recoveries were found to be in the range 94.5-104.1\% which are not that impressive. As low as $0.02 \mu \mathrm{g} / \mathrm{ml}$ of platinum and palladium were determined by ICP-AES after preconcentration from $5 \mathrm{~mol} \mathrm{l}^{-1} \mathrm{HCl}-\mathrm{pH} 9$ solutions with macroporous poly(vinyl thiopropionamide) chelating resin synthesized from spherical poly(vinyl chloride) resin particles $/ 38 /$. The adsorption capacities were calculated to be 288 and $455 \mathrm{mg} / \mathrm{g}$ for platinum and palladium respectively. The lowest concentrations that could be determined were $\sim 0.04 \mu \mathrm{g} / \mathrm{ml}$. Dithizone anchored poly(vinylpyridine) based chelating resin was prepared via the reaction between chloromethylated poly(vinyl pyridine) and dithizone 139/. The resin shows high affinity towards palladium(II) and platinum(IV). 100 and $250 \mathrm{mg} / \mathrm{g}$ palladium and platinum loadings were achieved which are higher than other chelating resins. Mixtures of $0.1 \mathrm{~mol} / 1 \mathrm{HCl}$ and $1.0 \%$ thiourea or $0.1 \mathrm{~mol} / 1 \mathrm{HCl}$ and $5.0 \%$ thiourea could elute palladium(II) and platinum(IV) quantitatively. 


\section{Coprecipitation}

\section{i) Platinum and palladium}

Platinum group elements which include platinum and palladium were preconcentrated and separated from large amounts of matrix elements by using tellurium coprecipitation /40/. The detection limits of the above preconcentration method in conjunction with ICP-MS are in the range 1-9 $\mathrm{pg} / \mathrm{g}$, which is quite good compared to other preconcentration methods. The results obtained on analysis of various reference materials agreed well with the certified values.

\section{Electrodeposition}

\section{i) Palladium}

Ohta et al. $141 /$ have developed a new preconcentration method using a $\mathrm{Mg}-\mathrm{W}$ cell electrodeposition which allows the determination of as low as $0.37 \mathrm{ng} / \mathrm{ml}$ of palladium in conjunction with electrothermal AAS (ETAAS). This preconcentration procedure does not need a power supply (electric source) like a potentiostat or battery. The same authors /42/ have applied the above procedure for determination of palladium in environmental samples with an average recovery of $102-114 \%$ which is rather poor.

Palladium(II) was selectively accumulated using sodium humate modified carbon paste $/ 43$ / electrode in $\mathrm{pH} 2.8$ (quite critical) Britton-Robinson buffer (B-R) in open circuit mode and determined subsequently by using cyclic voltammetry $(\mathrm{CV})$ and linear sweep anodic stripping voltammetry (LSASV) in $1.0 \mathrm{~mol} / \mathrm{l} \mathrm{HCl}$ as supporting electrolyte. Palladium concentrations in the range $9.4 \times 10^{-8}-4.7 \times 10^{-6} \mathrm{~mol} / 1$ could be determined.

The inner wall of a pyrotically coated graphite tube served as the surface for adsorptive accumulation and/or for electrodeposition of palladium and platinum /43/. After the deposition step, the graphite tube was placed into the graphite furnace and an atomization programme was employed. The developed procedure was successfully applied for the analysis of palladium and platinum in air borne particulates 


\section{E. Fire assay}

\section{i) Palladium and platinum}

The effects of various factors, viz. composition of mixture, relations between the mass of mixture and sample, value of the $\mathrm{Ni}: \mathrm{S}$ ratio, fusion time and temperature on the fine assay preconcentration of noble metals with nickel sulphide were investigated $/ 44 /$. The developed method in conjunction with NAA can be used for the determination of as low as $0.001-0.1 \mathrm{ng} / \mathrm{ml}$ of noble metal ores, stones, iron meterorites, chromites, soils and lunar rocks. McDonald et al. $146 /$ and Biosvert et al. $147 /$ have developed similar procedures for the analysis of South African Kimberlites and rocks respectively. Juvonen et al. $148 /$ determined platinum group metals by ICPMS and NAA after nickel sulphide fire assay preconcentration of black shale, magnetite samples and samples containing $\mathrm{As}$. $\mathrm{Cu}$ and $\mathrm{Fe}$.

Li et al. 149/ determined platinum group elements in Russian candidate reference materials by ICPMS after nickel sulphide fire assay preconcentration. Sulphide fire assay $150 /$ preconcentration procedures were developed for the estimation of platinum group metals in copper-nickel ores. The detection limits were $0.001-0.06 \mathrm{mg} / \mathrm{Kg}$ for a $5 \mathrm{~g}$ sample and an extract volume of $5 \mathrm{ml}$. The precision is moderate as it varied between 2-17\%. The platinum group metals present in some geological samples were preconcentrated in lead buttons through fire assay technique and determined by NAA /51/.

\section{F. Solid phase extraction}

Pyrzynska /52/ and Vlsankova and Sommer / I/ have reviewed recent advances in solid phase extraction preconcentration of platinum and palladium and platinum group metals in environmental and biotic materials respectively in 1999.

\section{i) Palladium}

Both batch and column preconcentration procedures were employed for the enrichment of palladium using naphthalene/benzophenone as solid phase extractants. The salient features of these procedures are summarized in Table 2.

A novel polyacrylamino imidazole chelating fibre is synthesized simply from nitrilon (an acrylonitrile based synthetic fibre) and used for 


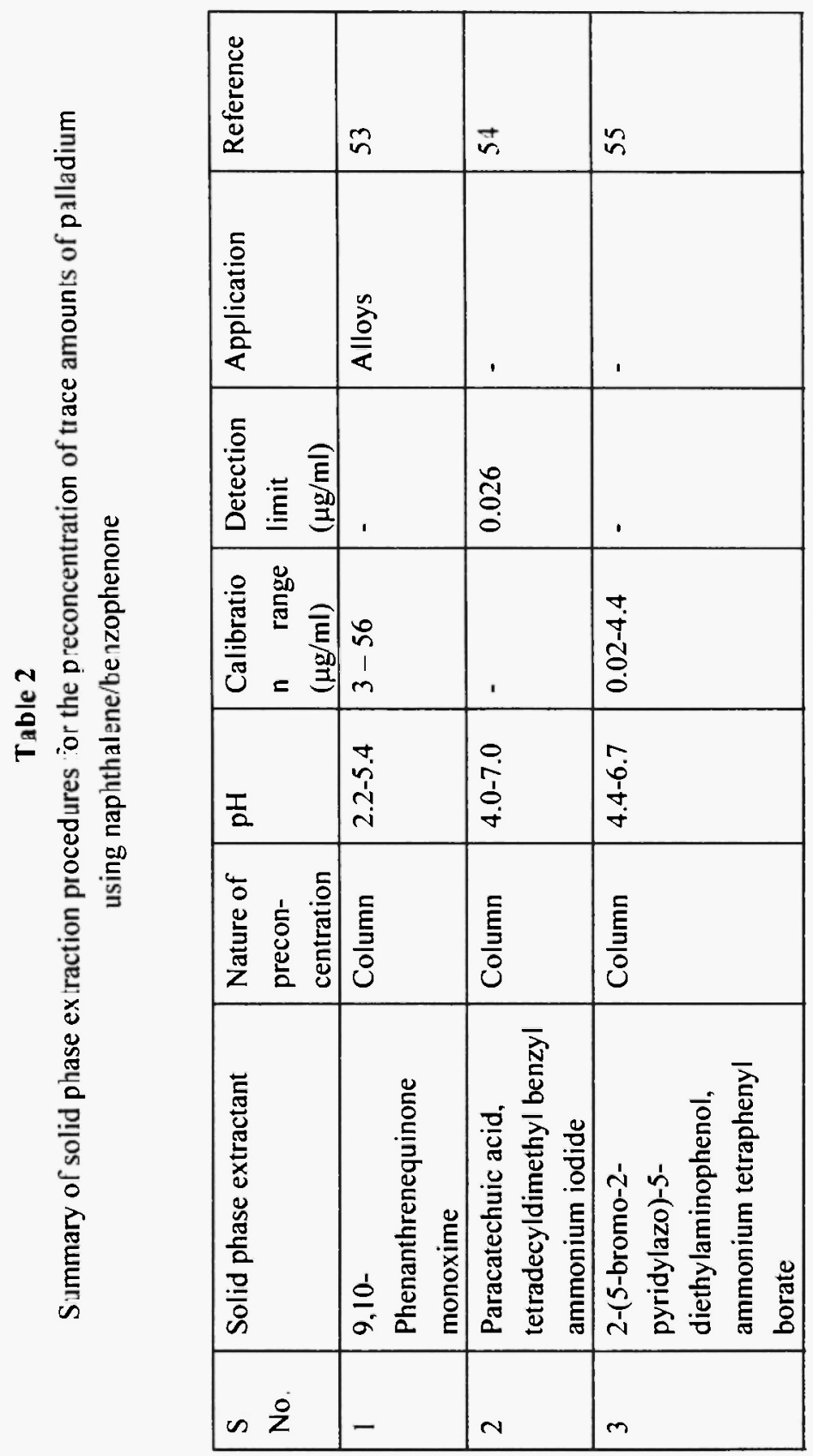




\begin{tabular}{|c|c|c|c|c|}
\hline$\because R$ & in & $\begin{array}{l}\infty \\
\infty\end{array}$ & 2 & 8 \\
\hline 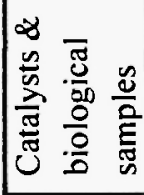 & ' & ' & $\begin{array}{l}\overline{0} \\
0 \\
\frac{0}{5} \\
\frac{5}{0} \\
2 \\
2\end{array}$ & \\
\hline$\frac{-}{0}$ & ' & 号 & $\stackrel{\wp}{8}$ & $\stackrel{m}{\rho}$ \\
\hline 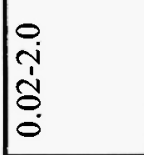 & $\begin{array}{l}\stackrel{8}{7} \\
\text { do } \\
\stackrel{0}{0}\end{array}$ & 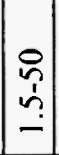 & 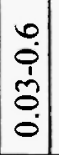 & $\frac{\tilde{r}}{\dot{q}}$ \\
\hline $\begin{array}{l}n \\
n \\
n \\
n \\
m\end{array}$ & $\frac{0}{\dot{r}}$ & $\mid \begin{array}{c}0 \\
\dot{i} \\
\hat{j} \\
i\end{array}$ & & $\begin{array}{l}n \\
0 \\
0 \\
\grave{1} \\
i\end{array}$ \\
\hline 高 & 高 & 哣 & 离 & 音 \\
\hline 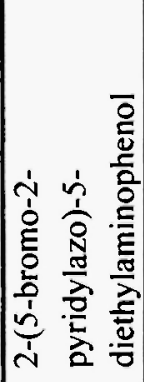 & 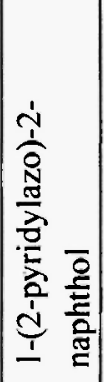 & 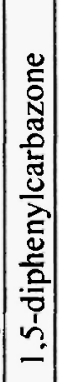 & 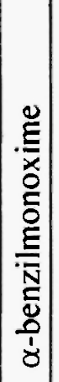 & 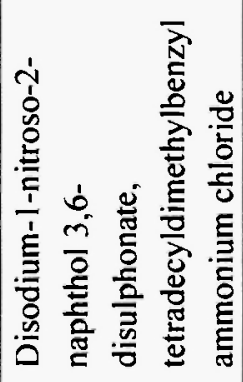 \\
\hline$\nabla$ & $n$ & 0 & - & $\infty$ \\
\hline
\end{tabular}


preconcentration of palladium(II) from $\mathrm{pH} 3.0$ solutions at a significantly high flow rate of $15.0 \mathrm{ml} / \mathrm{min} / 61 /$. The adsorption capacity is $2.92 \mathrm{mmol} / \mathrm{g}$ which is quite good. The preconcentrated palladium(II) can be desorbed with $15 \mathrm{ml}$ of $4 \mathrm{~mol} / / \mathrm{HCl}+3 \%$ thiourea from the fibre column. The chelating fibre is reused 10 times with good recoveries of $97-99 \%$. Polyacrylacylisothiourea chelating fibre $162 /$ was synthesized using polyacrylonitrile fibre as starting material and used for preconcentration of as low as $0.008 \mu \mathrm{g} / \mathrm{ml}$ of palladium(IV) with a precision of $2.5 \%$. New macroporous polymers with an ionogenic group based on triisobutyl phosphine sulphide, with spacer arms containing $\mathrm{O}$ or $\mathrm{S}$ atoms were reevaluated for preconcentration of palladium(II) in the presence of other platinum groups and base metals $163,64 /$. The chelating polymer can be reused for 15 times with good recoveries. Ring opening-metathesis polymerization was used for the preparation of dipyridylcarbamide functionalized polymer suitable for SPE preconcentration of palladium(II) from aqueous solutions $/ 65 /$. This material showed excellent selectivity for palladium(II) over other divalent metal ions over a broad range of concentrations from complex mixtures.

Silica modified with $\mathrm{N}$-allyl-N'-propyl thiourea $/ 66 /$ and chemically modified nitrogen containing ligands $167 /$ were employed for the preconcentration of palladium(II) and determined by FAAS and X-ray fluorescence (XRF) spectrometry. The detection limits are 0.05 and 0.01 $\mu \mathrm{g} / \mathrm{ml}$ respectively.

SPE preconcentration procedures were developed for palladium(II) using activated carbon columns $/ 68-70 /$. The latter two procedures are applied for the analysis of geological samples /69/ and aluminium and manganese salts $170 /$ in conjunction with FAAS. The precision of these procedures is rather poor $(-10 \%)$ for 5 successive determinations.

Ion imprinted solid phase extraction preconcentration procedure was developed for enrichment of $2.5-100 \mu \mathrm{g} / \mathrm{l}$ of palladium(II) $/ 7 \mathrm{l} /$. Ion imprinted polymer materials were prepared by formation of ternary complex of palladium imprint ion with dimethyl glyoxime and vinyl pyridine (functional monomer) and thermally copolymerizing with styrene (crosslinking monomer) and divinyl benzene (crosslinker) and 2,2'-azobisisobutyronitrile as initiator. The synthesis was carried out with cyclohexanol as porogen and subsequently the imprint ion was leached with $1: 1 \mathrm{HCl}$ to obtain leached IIP particles. These leached IIP particles can now pick up palladium ions from dilute aqueous solutions. The selectivity of ion imprinted polymer for 
palladium with respect to platinum, copper, zinc and nickel are 100 times higher compared to ion recognition (blank) polymer prepared under identical conditions. The retention/binding capacity of Pd selective IIP was calculated to be $21.5 \mu \mathrm{g} / \mathrm{g}$, which is much higher than other imprinted procedures. $\gamma$-Irradiation of unleached IIP particles results in quantitative enrichment of palladium even with half the amount of imprint ion ( $\mathrm{Pd}^{-}$) during imprinting.

\section{ii) Platinum}

Modified silica gel was employed for preconcentration of 2-20 $\mu \mathrm{g}$ platinum present in plant ash from $0.1 \mathrm{~mol} / \mathrm{l} \mathrm{HCl}$ in the presence of cationic surfactants, especially dimethyl lauryl benzyl ammonium bromide. with subsequent elution with $96 \%$ ethanol $/ 72 /$. The recoveries vary from $86-110 \%$ for $2 \mu \mathrm{g}$ of platinum and average RSD was $6.3 \%$.

\section{iii) Platinum and palladium}

Sequential SPE preconcentration of platinum(IV) and palladium(ll) from thiocyanate solutions was achieved by passing through an organic impregnated filter (OIP) /73/. The extraction of both metals is rapid with quantitative recoveries from flow rates of as high as $600 \mathrm{ml} / \mathrm{min}$. Once extracted, the metals can be removed from the OIP by conversion to a nonextractable form with a high $\mathrm{pH}$ eluting solution. The validity or application of the developed procedure was not tested by the authors. Polyacrylacylaminothiourea chelating fibre was synthesized simply and rapidly from nitrilon and aminothiourea and successfully used for a 100 fold enrichment of platinum(IV) and palladium(IV) from dilute solutions /74/. The precision and recoveries are $0.7 \%$ and $96-100 \%$ respectively which are quite impressive. The accuracy of the developed procedure was tested by analysing certified reference materials (CRM).

Platinum and palladium were preconcentrated from $\mathrm{pH} \leq 5.0$ solutions onto 2-mercaptobenzothiazole bonded silica gel (MBTSG) prior to their determination by ICP AES /75/. MBTSG was synthesised by the Mannich reaction between 2 -mercaptobenzothiazole and 2-aminopropylsilica gel. The adsorbed metals can be readily desorbed with $3 \%$ thiourea in $3.0 \mathrm{~mol} / \mathrm{l}$ of $\mathrm{HCl}$ solutions. Very high enrichment factors, i.e. $\sim 250$. can be obtained and offer detection limits of $-2 \mathrm{ng} / \mathrm{ml}$. The adsorption capacity for palladium(II) is $18 \mathrm{mg} / \mathrm{g}$ of dry MBTSG, which is quite high but slightly less in the case of platinum(IV) $(6.5 \mathrm{mg} / \mathrm{g})$. 
Platinum and palladium in fresh waters was analysed by ICP-MS following their preconcentration by adsorption onto activated charcoal /76/. Using $1.0 \mathrm{I}$ of sample volume, a very high preconcentration factor of 200 was achieved by these authors with detection limits of $0.3-0.8 \mathrm{ng} / \mathrm{l}$ for both elements. The developed method has been successfully employed for the determination of platinum and palladium present in waters collected from various mineralized sites in Canada.

\section{G. On-line preconcentration techniques}

\section{i) Palladium}

Liu et al. $/ 77 /$ have synthesized new silica gel based chelating sorbent with thourea as a functional group, and this was used for the flow injection (FI) on-line preconcentration and separation of traces of palladium. Its sorption characteristics were evaluated by Fl-FAAS. Palladium is preconcentrated on thiourea modified silica gel with a sampling flow rate of $5.0 \mathrm{ml} / \mathrm{min}$ and eluted with $5 \%$ thiourea with a flow rate of $2.5 \mathrm{ml} / \mathrm{min}$ and determined by FAAS. The detection limit corresponding to 3 times of the standard deviation of the blank $(3 \sigma)$ is $21 \mathrm{ng} / \mathrm{ml}$ with a I minute sample loading time. The RSD is $<3.0 \%$ with $0.30 \mu \mathrm{g} / \mathrm{ml}$ of palladium. The total dynamic capacity of sorbent is very high, i.e. $30.3 \mathrm{mg} / \mathrm{g}$, and exhibited excellent stability as the sorption properties do not change even after 1000 cycles of use. The developed method has been successfully used for the analysis of palladium in secondary nickel alloy, anode slime, electrolytic solution and three national certified ore samples.

Amidinothioureido /78/ and rhodanine /79/ bonded silica gel column materials were employed during flow injection online preconcentation and flame AAS determination of palladium over a wide range of acidity 0.1-6.0 mol/l $\mathrm{HNO}_{3}$ or $\mathrm{HCl}$. The analytical procedures were optimized for sample acidity, elution, interferences, sampling and eluting flow rates and concentration of sample. Common co-existing cations and anions did not interfere with the preconcentration and determination. Detection limits of 0.017 and $0.019 \mu \mathrm{g} / \mathrm{ml}$ were obtained with loading flow rates of $4.5 / 78 /$ and $5.0 / 79 / \mathrm{ml} / \mathrm{min}$, with $60 \mathrm{~s}$ preconcentration. The detection limits can be further improved by increasing sample volume. The analytical results obtained by the above methods were in good agreement with the certified values for a number of standard reference materials. A fully automated online column separation and preconcentration system was described for the 
determination of trace and ultratrace levels of palladium by GF AAS $180 \%$. Palladium was preconcentrated in a microcolumn which was reversibly loaded with $\mathrm{N}, \mathrm{N}$-diethyl-N'-benzoyl thiourea as selective complexing agent. The palladium complex was eluted with $60 \mu \mathrm{l}$ of ethanol and directly introduced into the graphite furnace. Sensitivity enhancements of 40,70 and 200 can be obtained for sample volumes of $0.80,1.86$ and $4.85 \mathrm{ml}$ respectively. The corresponding detection limits are 51,25 and $13 \mathrm{ng} / \mathrm{l}$. Several alkali, alkaline earth and base metal ions such as copper(II), iron(III), cobalt(II) and $\mathrm{Ni}(\mathrm{III})$ etc., as well as precious metals, were tolerated up to concentrations of $10 \mathrm{~g} / \mathrm{l}$ and more. The precision of the developed procedure is also good as the RSD was in the range $1.7-2.9 \%$.

Palladium was determined in pharmaceuticals by direct GFAAS method with a detection limit of $0.1 \mu \mathrm{g} / \mathrm{g}$ in $5 \%$ solution $/ 81 /$ The recovery of $0.5-$ $7.0 \mu \mathrm{g} / \mathrm{g}$ palladium spike was close to $100 \%$. The Fl-GFAAS method developed by Schuster and Schwarzer /79/ utilized oxime and iminodiacetic acid ethylcellulose microcolumns for palladium in aqueous and $50 \%$ methanol solutions. The optimal $\mathrm{pH}$ range for preconcentration was $2-5$. The detection limits were $0.33 \mu \mathrm{g} / \mathrm{l}$ and $0.42 \mu \mathrm{g} / \mathrm{l}$ for oxime and iminodiacetic acid ethyl cellulose respectively providing an overall 20 fold enrichment.

A flow system comprising of a microcolumn packed with activated carbon fibre was used for the preconcentration of palladium /82/. The method was sensitive and operated easily with a sampling rate of $15-20 / \mathrm{h}$. The detection limit of this FI-FAAS method was $0.3 \mu \mathrm{g} / \mathrm{l}$ in standard solution and the precision is $3.9 \%$ (RSD) for $50 \mathrm{ng} / \mathrm{ml}$ of palladium solution. The recovery of palladium spiked solutions was $103-107 \%$ which was a little on the high side. A new on-line column separation and preconcentration system for the selective determination of trace and ultratrace levels of palladium was described using FI-GFAAS /83/. Sensitivity enhancements of 40, 70, 200 and 1200 could be obtained from sample volumes of $0.8,1.86,4.85$ and $45 \mathrm{ml}$ respectively. The corresponding detection limits were $51,25,13$ and $3 \mathrm{ng} / 1$. In $1.4 \mathrm{~mol} / \mathrm{L} \mathrm{HNO}_{3}$ solutions alkali, alkaline earth, and base metal ions such as $\mathrm{Cu}(\mathrm{II}), \mathrm{Zn}(\mathrm{II}), \mathrm{Fe}(\mathrm{III}), \mathrm{Co}(\mathrm{II})$, and $\mathrm{Ni}(\mathrm{II})$ as well as precious metals were tolerated up to concentrations of $10 \mathrm{~g} / \mathrm{l}$ and more. The RSD values were in the range $1.7-2.9 \%$ which are quite good.

\section{ii) Platinum}

A flow injection on-line preconcentration and separation system with microwave assisted desorption is proposed for the FAAS determination of 
trace amounts of platinum $/ 84 /$ using thiourea modified silica gel column. $2 \%$ thiourea was used to elute the adsorbed platinum into the nebulizer of the spectrometer with microwave irradiation. Common co-existing ions did not interfere in the determination of platinum(IV). The RSD for determination of $1.0 \mu \mathrm{g} / \mathrm{ml}$ was $<4 \%$ with $120 \mathrm{~s}$ of preconcentration at a sampling flow rate of $2.5 \mathrm{ml} / \mathrm{min}$. The detection limit corresponding to 3 times the standard deviation of the blank was found to be $0.060 \mu \mathrm{g} / \mathrm{ml}$. The results obtained by the proposed method for 3 types of metallurgical samples, a secondary nickel alloy, anode slime and cobalt chloride solution, were in good agreement with recommended values. A flow injection on-line sorption preconcentration method for the ET-AAS determination of platinum has been developed /85/. The pyrollidine dithiocarbamate complexes of either platinum(IV) or platinum(II), formed in $0.7 \mathrm{~mol} / \mathrm{I} \mathrm{HNO}_{3}$ are online adsorbed on the inner walls of PTFE knotted reactor and subsequently eluted with methanol. A very good enhancement factor of 112 and a detection limit of $10 \mathrm{ng} / \mathrm{l}$ along with a sampling frequency of $21 / \mathrm{h}$ were achieved with a $90 \mathrm{~s}$ preconcentration time at a sample flow rate of $8.8 \mathrm{ml} / \mathrm{min}$. The RSD is $2.5 \%$ for $0.4 \mu \mathrm{g} / \mathrm{l}$ of platinum. The method has been applied to the determination of platinum in blood samples.

On-line preconcentration of platinum was carried out by using alumina microcolumn with subsequent detection by FAAS $/ 86 /$ on ICP-AES $/ 87 /$. The preconcentration factors were calculated to be 600 ( $25 \mathrm{ml}$ elution volume) and 25.5 respectively. The precision is rather poor in both cases as the RSD values were $9 \%$ (at $0.1 \mathrm{mg} / \mathrm{l}$ solution) and $5 \%$ (at $0.72 \mathrm{mg} / \mathrm{l}$ ) respectively. The former procedure was found to be suitable for the determination of platinum in natural water samples. A flow injection system incorporating an alumina microcolumn has been coupled to ICP-MS for on-line preconcentration and determination of platinum(IV) in natural waters $/ 88$. A very high enrichment factor of 600 could be achieved by eluting with $50 \mu \mathrm{l}$ of $2 \mathrm{~mol} / \mathrm{l}$ of $\mathrm{NH}_{4} \mathrm{OH}$. The limit of detection after a 5 minutes preconcentration time was $4 \mathrm{ng} / \mathrm{l}$ with a relative standard deviation of $4 \%$ (at $100 \mathrm{ng} / \mathrm{l}$ of working solution).

An on-line preconcentration using electrode position onto a flow through graphite tube cell coupled to an ET-AAS was developed for preconcentration and determination of platinum $/ 89 /$. After the deposition step, the graphite tube was placed into the graphite furnace and atomization programme was applied. The utility of the proposed procedure was checked with the analysis of series of samples in the range of platinum concentrations from 0.1 to 10 $\mathrm{ng} / \mathrm{nl}$ for 30 minutes deposition. Platinum present in tobacco, beans, slag and 
dust samples was electrochemically deposited at -0.9 to $-1.2 \mathrm{~V}$ in a flow system incorporating 3-electrode flow-through cell with a graphite counter and $\mathrm{Ag} / \mathrm{AgCl}$ reference electrodes after mineralization with nitric and hydrochloric acids in high pressure PTFE bomb /90/. A pyrolytically coated graphite tube packed with reticulated vitreous carbon (RVC) served as the working electrode with RVC filling axially bored to let the light beam pass through the tube during the GF-AAS measurements. This opening was plugged with a glass rod during the preconcentration step. After the electrodeposition, the tube was placed in the graphite furnace and an atomization temperature of $2700^{\circ} \mathrm{C}$ was applied. The geometry of the cell. flow rate for electrodeposition, deposition potential and electrolyte composition were optimized. The absolute detection limit was found to be about $0.3 \mathrm{ng}$ of platinum.

\section{iii) Platinum and palladium}

A simple and highly selective flow injection on-line preconcentrative separation FAAS method was developed for routine analysis of trace amounts of palladium and platinum in geological and metallurgical samples 191\%. The selective preconcentration of noble metals was achieved over a wide range of acidities (0.5-3.0 mol// $\mathrm{HNO}_{3}$ or $\left.\mathrm{HCl}\right)$ on a microcolumn packed with an isodiphenyl thiourea immobilized silica gel. The noble metals retained on the microcolumn were effectively eluted with thourea solution. $25.0 \mathrm{mg} / \mathrm{ml}$ of common base metal ions and $100.0 \mathrm{mg} / \mathrm{ml}$ of anions were tolerated during the determination of $0.20 \mu \mathrm{g} / \mathrm{ml}$ of palladium(II) and 1.0 $\mu \mathrm{g} / \mathrm{ml}$ of platinum(IV) were preconcentrated for $60 \mathrm{~s}$ with a sample flow rate of $5.0 \mathrm{ml} / \mathrm{min}$. The detection limits were 4.7 and $69 \mathrm{ng} / \mathrm{mll}$ for palladium(II) and platinum(IV) respectively with the RSD being $<3.0 \%$. The accuracy of the proposed method was tested by analyzing geological and metallurgical CRM's.

A flow injection on-line microcolumn method packed with $\alpha$ aminopyridine resin has been studied for the preconcentration and separation of noble metals followed by FAAS determination $192 \%$ Non-noble metals could be eliminated by $2 \mathrm{~mol} / \mathrm{I} \mathrm{HCl}$ as rinsing solution. Separation of individual noble metals could also be accomplished using selective eluents. The method has been applied to certified samples. Bogacheva '/ al. 93/ have developed a flow injection FAAS method for palladium and platinum determination in solution. This procedure includes sorption preconcentration of platinum/palladium ion associates with n-octyldiethyllenetriamine using 
reversed phase styrene-divinyl benzene copolymer. The detection limits of 5 and $3 \mu \mathrm{g} / \mathrm{l}$ for palladium and platinum respectively for I minute of preconcentration and sampling frequency of $40 / \mathrm{h}$ were achieved.

A flow system combined with segmentation technique was used to develop an efficient on-line sorbent extraction preconcentration system for palladium and platinum for subsequent determination of GFAAS or ICP-AES 194/. The detection limits were 0.03 and $0.1 \mathrm{ng} / \mathrm{ml}$ for palladium and platinum respectively, using GFAAS detection. The method was applied to the analysis of polluted biological materials.

Ultratrace determination of platinum group metals in environmental samples was achieved by depositing on the inner wall of a graphite tube in a flow through cell of $1 \mathrm{ml}$ volume $/ 95 /$. For electrodeposition, a 3-electrode arrangement was used. The geometry of the cell, flow rate during electrodeposition, deposition potential and electrolyte composition were optimized. After the deposition step, the graphite tube was placed into the graphite furnace and an atomization programme was applied. The detection limits corresponding to 3 times the standard deviation of the blank were 3.6 and $0.5 \mathrm{ng}$ for platinum and palladium respectively, reflecting preconcentration factors of 416 and 503 respectively. Reasonable agreement was found between the results obtained for $\mathrm{CW} 7$ road tunnel dust and NIES No.8 CRM for vehicle exhaust particulates.

\section{CONCLUSIONS}

Cation or anion exchange has been used traditionally for preconcentration/separation of platinum and palladium. Being environmentally friendly, this technique still finds application in recent times. However, the chief drawbacks are frequent replacement of resins and low enrichment factors associated with this preconcentration technique. Coprecipitation, though used historically, is not being actively pursued nowadays for preconcentration as the matrix is replaced by the coprecipitant added to enrich analyte. Flotation, although finding widespread use in beneficiation of lean minerals of platinum and palladium, requires the use of major quantities of toxic chemicals as floating agents and cannot be reused. Electrodeposition is a clean preconcentration technique with high enrichment factors but involves high costs compared to other preconcentration 
techniques. Fire assay was traditionally adopted for noble metal preconcentration/separation but has found limited application in recent times.

Liquid-liquid extraction (LLE) has been widely employed for preconcentration/separation of noble metals also in view of simplicity, reuse capability and ready adoptability to scale up. However, enrichment factors of around $\sim 10$ only can be obtained in view of the phase separation problems. In addition, emulsion formation necessitating the use of diluent and/or modifier and requirement of toxic chemicals in large volumes are other drawbacks of this technique. On the other hand, solid phase extraction is currently more popular as it is environmentally friendly and low cost, and has good reuse capability, ability to provide enrichment factors of 100-1000 and ease of automation. The future scenario in the area of preconcentration of trace and ultratrace amounts of noble metals - in particular platinum and palladium involves increased use of solid phase extraction preconcentration both in offline and online flow injection modes.

\section{ACKNOWLEDGEMENT}

One of the authors, Miss Sobhi Daniel, thanks the Council of Scientific and Industrial Research, New Delhi, India for providing the Junior Research Fellowship.

\section{REFERENCES}

1. T.S. West, Trace Characterisation, Chemical and Physical, NBS Monograph 100, National Bureau of Standards, Washington, DC, 1967.

2. E.J. Underwood, Trace Elements in Human and Animal Nutrition, Acad. Press, New York (1971).

3. G.H. Morrison, Trace Analysis, Acad. Pub., New York, 1981.

4. I.M. Kolthoff and P.J. Elwing, Treatise on Analytical Chemistry, Part II, Vol.8 (1963) p 384.

5. M.J. Abrams and B.A. Murrer, Science, 261, 726 (1993).

6. Yi Bin Qu, Analyst, 121, 139 (1996).

7. A. Mizuike, Enrichment Techniques for Inorganic Trace Analysis, Springer-Verlag, Berlin, 1983. 
8. T. Prasada Rao and J. Mary Gladis, Reviews in Anal. Chem., 20, 145 (2001).

9. T. Prasada Rao and J. Mary Gladis, Anal. Sci., 18, 517 (2002).

10. C.R.M. Rao and G.S. Reddy, Trends in Anal. Chem., 19, 565 (2000).

11. R. Vlasankova and L. Sommer, Chem. Papers, 53, 200 (1999).

12. P. Tarapcik and M. Vanickova, Chem. Papers, 46, 293 (1992).

13. K.Z. Hossain and T. Honjo, Fresenius J. Anal. Chem., 367, 141 (2000).

14. L. Yang, F.Q. Zhou, H.F. Peng, T.G. Zeng and S.H. Long. Chinese J. Anal. Chem., 29, 1402 (2001).

15. M. Balcerzak and E. Wyrzykowska, Analysis, 27, 829 (1999).

16. A.T. Yordanov and D.M. Roundhill, Inorg. Chim. Acta, 264. 309 (1997).

17. A.R. Pillai, K.K. Ramachandran and T. Prasada Rao, Chemia Analit., 43, 41 (1998).

18. L. Elci, Anal. Lett., 26, 1025 (1993).

19. A. Tunceli and A.R. Turker, Anal. Sci., 16, 81 (2000).

20. M. Iglesias, E. Antico and V. Salvado, Anal. Chim. Acta, 381, 61 (1999).

21. H. Aoki, H. Murakami and M. Chikuma, Bunseki Kagaku, 42, 147 (1993).

22. B.L. Gong, X.Q. Li, F.R. Wang and X-J. Chang, Chem. Res. In Chinese Universities, 17, 168 (2001).

23. X-J. Chang, X.Y. Luo, G.Y. Zhan and Z.X. Su, Talanta, 39, 937 (1992)

24. C.S. Li, C.F. Chai, X.F. Yang, X.L. Hou and X.Y. Mao, Talanta, 44. 1313 (1997).

25. K. Akatsuka, S. Hoshi, J.W. McLaren and S.S. Berman, Bunseki Kagaku, 43, 61 (1994).

26. C.Y. Liu, M.J. Chen and T.J. Chai, J. Chromatogr., 555, 291 (1991).

27. Z.X. Chen, B.J. Fryer, H.P. Longerich and S.E. Jackson, J. Anal. At. Spectrom., 11, 805 (1996).

28. B. Godlewskazylkiewicz, B. Lesniewska, U. Gasiewska and A. Hulanicki, Anal. Lett., 33, 2805 (2000).

29. I. Matsubara, Y. Takeda and K. Ishida, Fresenius J. Anal. Chem., 366, 213 (2000).

30. X.X. Dai, C. Koeberl and H. Froschl, Anal. Chim. Acta, 436, 79 (2001).

31. K.S. Choi, C.H. Lee, Y.J. Park, K.S. Joe and W.H. Kim, Bulletin of Korean Chem. Soc., 22, 801 (2001). 
32. C.L. Bao, S.J. Zhao, G.M. Liu, B. Zhou and Z.B. Feng, Chinese J. of Anal. Chem., 30, 198 (2002).

33. Z. Samczynski. B. Danko and R. Dybczynski. ('hemia, Analit., 45. 843 (2000).

34. A.G. Coedo, M.T. Dorado, I. Padilla and F. Alguacil, Anal. Chim. Acta. 340, 31 (1997).

35. X.J. Chang, Z.X. Su, D. Yang, B.L. Gong, Q.S. Pu and S.K. Li. Anal. Chim. Acta, 354, 143 (1997).

36. Z.X. Su, Q.S. Pu, X.Y. Luo, X.J. Chang. G.Y. Zhan and F.Z. Ren, Talanta, 42, 1127 (1995).

37. Z.W. Li. C.L. Bao and K. Zhang, Chem. J. Chinese Univ., 19, 1062 (1998).

38. Z.X. Su, X.J. Chang, K.L. Xu, X.Y. Luo and G.Y. Zhan, Anal. C'him. Acta. 268, 323 (1992).

39. R. Shah and S. Devi, Anal. Chim. Acta, 341, 217 (1997).

40. X.D. Jin and H.P. Zhu, J. Anal. At. Spectrom., 15. 747 (2000).

41. K. Ohta, J. Ogawa and T. Mizuno, Analysis, 25, I (1997).

42. K. Ohta, J. Ogawa and T. Mizuno, Fresenius J. Anal. Chem., 357, 995 (1997).

43. Q.Y. Sun, C.M. Wang, L.X. Li and H.L. Li, Fresenius J. Anal. C'hem., 363. 114 (1999).

44. J. Komarek, P. Krasensky, J. Balcar and P. Rehulka, Spectrochim. Acta. 54, 739 (1999).

45. G.M. Kolesov and D.Y. Sapozhnikov, Analyst, 120, 1461 (1995).

46. I. McDonald, R.J. Hart and M. Tredoux, Anal. Chim. Acta. 289, 237 (1994).

47. R. Boisvert, M. Bergeron and J. Turcotte, Anal. Chim. Acta, 246, 365 (1991).

48. R. Juvonen, T. Lakomaa and L. Soikkeli, Talanta, 58, 595 (2002).

49. C.S. Li, C.F. Chai, X.L. Li and X.Y. Mao, Geostandards Neristett. The J. of Geostandards and Geoanal., 22, 195 (1998).

50. V.G. Torgov, M.G. Demidova, T.M. Korda, N.K. Kalish and R.S. Shulman. Analyst, 121, 489 (1996).

51. S. Lahiri, D. Nayak. M. Nandy and N.R. Das, Radiochim. Acta, 73, 35 (1996).

52. K. Pyrzynska, Talanta, 47, 841 (1999).

53. S. Baiani and B.K. Puri, Talanta, 39. 815 (1992). 
54. M. Satake, J.R. Lee, B.K. Puri and M. Katyal, Indian J. of Chemistry, 31, 67 (1992).

55. M.A. Taher, Anal. Lett., 31, 2115 (1998).

56. J.P. Pancras and B.K. Puri, Anali. Di. Chimica, 89, 427 (1999).

57. M.A. Taher, S. Puri, M.K. Gupta and B.K. Puri, Indian J. Chem. Tech., 5, 321 ( 1998).

58. M.B. Gholivand, E. Garrosi and S. Khorsandipoor, Anal. Lėi., 33, 1645 (2000).

59. H. Eskandari, H.S. Ghaziaskar and A.A. Ensafi, Anal. Lett., 34, 2535 (2001).

60. M.A. Taher, Quimica Analitica, 19, 143 (2000).

61. B.L. Gong, Talanta, 57, 89 (2002).

62. X.J. Chang, Z.X. Su, G.Y. Zhan, X.Y. Luo and W.Y. Gao, Analyst, 119, 1445 (1994).

63. J.M. Sanchez, M. Hidalgo, M. Valiente and V. Salvado, J. Polymer Sci., 38, 269 (2000).

64. J.M. Sanchez, M. Hidalgo and V. Salvado, Reactive \& Functional Polymers, 49, 215 (2001).

65. F. Sinner, M.R. Buchmeiser, R. Tessadri, M. Mupa, K. Wurst and G.K. Bonn, J. Am. Chem. Soc., 120, 2790 (1998).

66. V.N. Losev, G.V. Volkova, N.V. Maznyak, A.K. Trofimchuk and E.Y. Yanovskaya, J. Anal. Chem., 54, 1109 (1999).

67. T.I. Tikhomirova, V.I. Fadeeva, G.V. Kudryavtsev, P.N. Nesterenko, V.M. Ivanov, A.T. Savitchev and N.S. Smirnova, Talanta, 38, 267 (1991).

68. M. Soylak and L. Elci, Anal. Lett., 33, 513 (2000).

69. H. Chakrapani, P.L. Mahanta, D.S.R. Murthy and B. Gomathy, Talanta, 53, 1139 (2001).

70. M. Soylak, L. Elci, I. Narin and M. Dogan, Asian J. Chemistry, 13, 699 (2001).

71. Sobhi Daniel, J. Mary Gladis and T. Prasada Rao, Anal. Chim. Acta. 488. 173 (2003).

72. V. Otruba, M. Strnadova and B. Skalnikova, Talanta, 40, 221 (1993).

73. R.D. Oleschuk and A. Chow, Talanta, 45, 1235 (1998).

74. B.L. Gong and Y. Wang, Anal. Biosanal. Chem., 372, 597 (2002).

75. Q.S. Pu, Z.X. Su, Z.H. Hu, X.J. Chang and M. Yang, J. Anal. At. Spectrom., 13, 249 (1998).

76. G.E.M. Hall and J.C. Pelchat, J. Anal. At. Spectrom., 8, 1059 (1993). 
77. P. Liu, Q.S. Pu and Z.X. Su, Analyst, 125, 147 (1999).

78. M. Schuster and M. Schwarzer, Anal. Chim. Acra, 328, I (1996).

79. A. Levai, A. Lasztity, K. Zihperenyi and Z. Horvath. Microchem. J., 58. 272 (1998).

80. S.L. Lin, C.S. Zheng and G.H. Yun, Talania, 42, 921 (1995).

81. M. Schuster and M. Schwarzer, Atomic Spectrosc., 19. 121 (1998).

82. S.M. Zhang, Q.H.Pu, P. Liu, Q.Y. Sun and Z.X. Su, Anal. Chim. Acra, 452, 223 (2002).

83. P. Liu, Q.S. Pu, Y. Sun and Z.X. Su, Fresenius J. Anal. Chem., 366. 816 (2000).

84. P. Liu, Q.S. Pu, Z.D. Hu and Z.X. Su, Analyst, 125. 1205 (2000).

85. E. Ivanova and F. Adams, Fresenius .J. Anal. (hem., 361, 445 (1998).

86. A. Cantarero, M.M. Gomez, C. Camara and M.A. Palacios, Anal. Chim. Acta, 296, 205 (1994).

87. J.F. Vanstaden, C.J. Redemeyer and S.M. Linsky, South .tfricun .J. Chem., 50, 115 (1997).

88. M.M. Hidalgo, M.M. Gomez and M.A. Palacios, Fresenius J. Anal. ('hem., 354, 420 (1996).

89. H. Matusiewicz, M. Lesinski, A. Ciszewski and B. Lewandowska. ('hemia Analit., 46, 199 (2001).

90. E. Beinvohr. M.L. Lee. P. Tschopel and G. Tolg. Fresenius .J. Anul. ('hem., 346, 689 (1993).

91. P. Liu, Z.X. Su, X.Z. Wu and Q.S. Pu, J. Anal. .4t. Spectrom.. 17, 125 (2002).

92. P. Di and D.E. Davey, Talanıa, 42, 685 (1995).

93. L.V. Bogacheva. I.A. Kovalev, G.I. Tsysin, A.A. Formanovsky, Yu. A. Zolotov. Mendeleev Commun.. 5. 171 (1998).

94. M.L. Lee, G. Tolg, E. Beinrohr and P. Tschopel, Anal. (him. Acra. 272. 193 (1993).

95. H. Matusiewicz and M. Lesinski. Int. J. Emiron. Anal. ('hem.. 82. 207 (2002). 
